\title{
The Age of Post-Truth: State Influence and Strate- gic Communication - Contemporary Security Challenges on Europe's Eastern Flank
}

\section{Ralf Roloff and Pál Dunay}

College of International and Security Studies, George C. Marshall European Center for Security Studies, http://www.marshallcenter.org

\begin{abstract}
The role of strategic communication has changed in the context of Russia's relations with its partners, including the West, the post-Soviet space and the Western Balkans since 2013 with the declaration of the close integration of communication with other means of Russian influence. Moscow has allocated more resources than ever and weakened the traditional western media superiority. However, it is not the media per se but its integration with the realization of strategic objectives that has represented the main differences compared to earlier times. It is not Russia's primary intention to convince but to raise doubt in the messages of other actors and gain influence in societies and over governments. In the area of the former Soviet Union, strategic messaging is part of a continuum that includes the eventual use of military force. The West faces a dilemma as it must not undermine its own values and must preserve the freedom of speech and the press while Russia protects its media monopoly and has effectively eliminated the freedom of electronic media at home. The West has reacted belatedly and hesitantly as far as its strategic messaging, although it is gradually catching up with taking certain counter-measures not only nationally but also through its institutions.
\end{abstract}

Keywords: Fake news, information warfare, media, Russia, state influence, strategic communication, strategic messaging. 


\section{Introduction}

Between 14-18 May 2018, the George C. Marshall European Center for Security Studies brought together 54 civilian, law enforcement and military mid- to senior level security policy practitioners and experts from 19 countries in order to collaborate on the third European Security Seminar-East (ESS-E). The course addressed "The Age of Post-Truth: State Influence and Strategic Communication Developing strategies to address contemporary security challenges on Europe's eastern flank." Not much later, between 4-8 June 2018, the Senior Executive Seminar (SES) followed on a related topic "Countering Hostile Influence Operations from State and Non-State Actors." The heightened attention to the topic is fully understandable as strategic communication has acquired new dimension over the past years. Addressing communication was also a logical continuation of the previous ESS-E that addressed hybrid threats and strengthening resilience. ${ }^{1}$ States whose propaganda machinery was neither particularly credible, nor successful, have changed their mechanisms and means to meet the challenges and better integrate communication with their strategies.

Although primary attention has been paid to the Russian Federation, for various reasons the strategic communication of many other actors should also be monitored more closely, in part because the means of addressing populations of other countries is more widely available and can be used more cost effectively than ever. This applies in particular to the decentralized use of social media. Partly, as although strategic communication is not a new phenomenon, " ...[h]ow they are used or how they are hidden in their use, is the new part of this hybrid war." 2

It is known that states cannot enjoy great power status unless they act and operate on a complex power base. It includes various elements, ranging from military power to a large and competitive economy, including innovation, a relatively youthful and educated population, a model that can be followed by other states and some who actually do follow the lead of the great power. Other factors, like a language spoken in some other countries and culture may also be listed among them. It is also essential that the country could reach out to others and its messages would carry some credibility. Some elements are more strongly present than others in different states. However, no state can belong to those at the "high table" that does not invest in a broad power spectrum. Smart states usually move from their strengths to weaknesses and reallocate resources accordingly. They may also allocate resources to their areas of strength in order to

1 For the outcome of that seminar see Pál Dunay and Ralf Roloff, "Hybrid Threats and Strengthening Resilience on Europe's Eastern Flank," Security Insights, no. 16 (March 2017), http://www.marshallcenter.org/mcpublicweb/mcdocs/files/College/F_Publi cations/seclnsights/security_insights_16.pdf.

2 Jim Garamone, "NATO Commander Breedlove Discusses Implications of Hybrid War," U.S. Department of Defense, March 23, 2015, www.defense.gov/News/Article/ Article/604334/nato-commander-breedlove-discusses-implications-of-hybrid-war/. 
make them even stronger. The former is horizontal strengthening (from strength to weakness), the latter is vertical (further strengthening in areas of strength). There are several examples to illustrate this point. China that has been the production hub of the world industry has diversified successfully its power base and developed a performant military, has become the second largest spender on defense and has also promoted the Chinese culture and language. As far as the Russian Federation, it has major strengths, like the world's largest arsenal of nuclear weapons, the largest land mass, the second largest oil and gas production, a large armed force, a large and well-trained diplomatic and intelligence service, and a sphere of influence in the former Soviet republics and to some extent elsewhere, like in Syria and in the Western Balkans.

Russia's predecessor, the Soviet Union, had spread propaganda internationally. However, as the Soviet Union was spreading an ideology that was not at all credible, its propaganda was successful only in those parts of the world where it was backed by the force of arms. ${ }^{3}$ The Russian Federation, which tripled its total GDP between 1999 and 2013, used its resources to diversify its activities to areas with perceived weaknesses compensating the flaws of its reach-out by international communication. Although we may address an enduring process, the development gained all the more attention when the Chief of the General Staff of the Russian Armed Forces, General Valeriy Gerasimov integrated the importance of communication in his "non-doctrine - doctrine." ${ }^{4}$ In sum, since 2014 an assertive strategic communication program has formed part and parcel of Russia's grand (and military) strategy. There are four notable aspects to emphasize:

1. Pragmatism. The external relations of the Russian Federation, in sharp contrast with the foreign relations of its predecessor, the Soviet Union, can be characterized as pragmatic. This gives more opportunity to communicate various messages without sticking to a set of incredible ideological tenets.

2. Strategic communication has been strongly integrated with a revised defense doctrine. This association created the impression that it is not part

3 As George Kennan generally put it: "Everyone imposes his own system as far as his army can reach. It cannot be otherwise." Cited in Louis Menand, "Getting Real: George F. Kennan's Cold War," The New Yorker, November 6, 2011, www.newyorker.com/ magazine/2011/11/14/getting-real.

4 Memorably, many spoke about the so-called Gerasimov doctrine, until the moment the 'inventor' of the term apologized for having invented it. Mark Galeotti, "I'm Sorry for Creating the 'Gerasimov Doctrine'," Foreign Policy, March 5, 2018, http://foreignpolicy.com/2018/03/05/im-sorry-for-creating-the-gerasimov-

doctrine/. Even though a similar conclusion had been drawn by Michael Kofman, "Mif o 'Doktrine Gerasimova': Amerikanskiy voennuy ekspert o tom pochemu rossiyskiy general stal znamenitostyu na Zapade (Myth about the 'Gerasimov Doctrine': American military expert about why the Russian general has become famous in the West)," Izvestiia, January 30, 2018, https//iz.ru/651301/maikl-kofman/mif-odoktrine-gerasimova, it was Galeotti who has given the impression that it was an exaggeration to speak about a full-fledged Gerasimov doctrine. 
of cooperation but confrontation. This was certainly unfortunate and alerted Russia's partners in Europe and North America.

3. It is a broader array of measures and activities that the world at large will have to be prepared to react to than just the strategic communication that is on the visible end of the political process.

4. The Russian leadership, due to the background of its several members, including President Putin, has considered favorably a more assertive campaign to communicate the country's messages to the world at large.

\section{The Challenge of Strategic Communication and How Severe It Is}

The fact that strategic communication and gaining state influence from it have become fashionable topics does not make it easier to adequately measure the role of this factor in interstate relations. It is certain that the Russian Federation has emerged as an actor that wants to influence its environment. In this sense Moscow is not different from any other state. However, there is difference as far as its ambitious and assertive appearance in the international scene to claim its place in communication internationally. Moscow has embraced active measures, the establishment of and financing front organizations, psychological operations, including generating hate, fear and hope. Another difference is that lately the Russian Federation has been active in a very broad spectrum of communication means and methods.

Among the means of communication we can see reliance on various media sources tailored to different audiences. Cost efficiency has been an issue here. Russia gives preference to electronic media, including social media and television. Russian national television is widely available in the area of the former Soviet Union, including the Baltic states. Its effect is noticeable when we take a look to opinion polls reflecting sympathy to Russia and the views represented by the Russian state. They are regularly higher where such programs are available. This means that Russian television programs, first and foremost channels like Pervuy Kanal and RTR Planeta achieve a lot in the immediate neighborhood of the country. Russia also uses international television broadcasting in various foreign languages. Russia Today television, or RT as it has been renamed, is available now in Arabic, English, French, German and Spanish. It is available both on satellite and in cable packages. RT also has an internet site in the same languages and also in Russian. It has been established and generously funded by the Russian state. $^{5}$

RT has been widely discussed internationally as a TV channel, spreading propaganda and often fake news. This went so far that French President Emanuel Macron, in a press conference held together with Russian President Vladimir Putin, pointed out that Russian state-backed media outlets, RT and Sputnik [are]

5 Executive Order on Measures to Make State Media More Effective; Executive Order on Measures to Raise Efficiency in the Work of State Mass Media Outlets, http://eng.kremlin.ru/acts/6387. 
'agents of influence' that spread falsehoods about him during his election campaign. ${ }^{6}$ Russia presents their activity differently and puts the emphasis on the contribution of RT to improving the image of the country in the world. It is apparent that the concerns are not so much about broadcasting per se but using it as platform to interfere in the internal politics of states, complementing other often hidden means. In sum, the concerns may well be related to a broader array, some kind of conglomerate of Russian power potential that includes the television program as part of it or as cover. The question is whether media communication is in its center or it is the complementary element of a set of more or less clandestine means. This is underlined by the fact the data about actual viewing of RT is unimpressive. For instance, in the UK, RT was never watched by more than in 4,300 households. On this basis it would be an exaggeration to regard it a source of major influence.

Russia is also projecting its messages on the internet using platforms like Sputnik (including Sputnik news) and various social media websites that project certain views. When they are compromised or "get beyond their shelf lives," they simply disappear and give place to new ones with more credibility. In print media, that has more limited influence on societies, Russia also applies a variety of means. That includes providing foreign journalists sympathizing with Russia with access to Russian leaders as well as providing easy access to the Russian version of different events. It is important that Russia provides journalists with information in many languages. Often, the quality of translation from Russian was closer to the early version of Google translate but more recently it has improved significantly, indicating Russian readiness to invest in translation. Western journalists pressed by time to deliver and not sacrificing time and energy to check facts are often glad to rely on easily accessible 'ready-made' information. Consequently, we can see a multiplicator effect of the Russian version of facts in the media of other countries.

Russia takes advantage of the unity of its own message and profits from a divided set of views in the West. This asymmetry presents a problem as it gives advantage to Russia that the West cannot compensate. Or actually, as will be presented later, an attempt to compensate and balance the asymmetry would entail political costs some of which the West cannot accept and bear. This contributes to the impression that the West is reactive and hesitant vis-a-vis unfriendly if not outright hostile Russian strategic communication.

A further complication results from information overload, when it is ever more difficult to identify reliable sources of information, especially as social media disaggregated the old patterns of communication and the new actors can directly reach out to the population of other countries. Similar concerns already appeared in the 1980s in conjunction with satellite television broadcasting that

6 Nicholas Vinocur, "Macron, standing by Putin, calls RT and Sputnik 'agents of influence'," Politico, May 29, 2017, https://www.politico.eu/article/macron-andputin-agree-on-restart-of-ukraine-talks/. 
provides access to the electronic media of the population in other countries. There are three factors to call for attention here:

1. Social media has made access more cost effective and influence hence can be 'bought' at a lower price

2. It is easier to send tailor-made messages, and

3. Some social media networks, including very wide-spread ones like Facebook, facilitate the reinforcement of perceptions by pre-selecting those messages that one allegedly sympathizes with in light of the record of messages red earlier. Other social media select what messages to emphasize on the basis of websites consulted earlier. This results in people reading messages that reaffirm their earlier views further deepening their conviction.

All this contributes to further deepening of political division in societies.

\section{Multitude of Problems Requiring Adequate Reaction}

The new opportunities for strategic communication involve numerous challenges that, apparently, require adequate response. However, finding the adequate and most effective response presents many difficulties. The reasons can be summarized as follows:

1. Strategic communication forms part of a broad political strategy, or as it is sometimes called, grand strategy, and thus the role of the former can only be assessed in light of the latter and the relationship between the two. Do states have grand strategy? Is strategic communication in line with the grand strategy of the state and does it contribute to it or is there discrepancy between the two?

2. The focus of strategic communication has changed over time. Whereas in 2014 Russian strategic communication focused primarily on spreading 'fake news' it has become more diversified lately. It has also become better integrated with other state activities as will be illustrated below.

3. The nature of hostile communication activities makes it difficult to react. They are often not spreading a cohesive alternative view of events/ developments but some variation that aims to undermine the still dominant-usually western-discourse. In other cases, it aims to deprive the West from the monopoly of its message. Last but not least, it occasionally appears as a 'moving target.' It changes the messages in order to retain the media presence and keep the focus of attention 'on message.'

4. The messages often combine elements of reality with falsehood. It also uses messages, where all the elements are in concord with facts but are 
connected in a manner that has unrelated issues look like closely related to each other. ${ }^{7}$

It is clear that the Russian Federation has a grand strategy that dates back to the consolidation of Russian statehood following the coming to power of Vladimir Putin. This is partly a reflection based on current and not so recent history. Namely, the starting point of the Russian Federation's strategy is that strong statehood is the only guarantee for the country's respect and international recognition. As the 1990s were identified with weak statehood, a discourse is being built that arbitrarily identifies weak statehood with chaos and liberalism as its underlying cause. This means that strong statehood is preferable in order to avoid malaise. If liberalism means weakness, strength should be associated with the denial of liberalism. A thorough analysis would prove easily that equating strong statehood with the denial of liberalism and weakness with liberalism is fundamentally false. However, what matters for the Russian leadership is the image generated in the country's population.

Although Russia's objectives have evolved over the last two decades, there are objectives that have remained largely unchanged. The grand strategy of the Russian Federation prioritizes status over achievement. Consequently, it is essential for the Russian leadership to present the country as highly successful. In some sense it is possible, as the ostensible political stability, including leadership stability, helps gain such an impression. Domestic strength is also portrayed as power internationally (which is not unusual for many states). However, due to the uneven level of the development of Russia, strategic communication is there to emphasize, among others, achievements and de-emphasize weakness. That is why it is often mentioned that the Russian leadership plays "a weak card strongly."

The most important international objective of Russia is to retain its independent statehood and sovereign political choice and restore its standing on the basis of power and strength. It is underlined by a declared assumption according to which when Russia took a conciliatory attitude in the 1990s, it was not 'rewarded' for it; on the contrary, its weakness was exploited by the West. While Russia is of the view that the perceived Western encroachment made its response necessary, western speakers do not share this view. Russia's main aspiration is to be a pole in a multipolar international system. In order to realize this

7 It is sufficient to mention an article that called the attention to the news that Poland would like to host U.S. forces permanently and is ready to spend a large amount (USD 2 billion) towards that purpose, adding that Poland will also open brothels for the troops stationed there. This title may contain elements that are in concord with the truth. Indeed, Poland would like to host a forward-deployed U.S. headquarters on its territory. If it is established, it might happen that there will be brothels in its vicinity. However, the latter will not be established by the Polish state but by the market if there is demand. Still, those that do not read the title with due attention may have false impressions. See Viktor Baranets, "V Pol'she zhdut yenki i gotovyat dlya nikh bordel (The Polish are waiting for the Yankees and prepare brothels for them)," Komsomol'skaya pravda, May 31 - June 6, 2018, 4. 
objective, Russia found necessary to maximize its relative power in the international system. As strengthening its own position faces limitations, first and foremost due to the limited role in the world economy and its weakness as a role model - an important element of soft power, this can be achieved, according to Russia's understanding, by the relative weakening of other centers of power. Targets in this respect may be the composite elements, i.e. individual states, and elements that contribute to their cohesion, including alliances and other integration formats. The Russian Federation applies various means to weaken states and alliances. However, doubts are expressed widely whether the means thus used are appropriate and proportionate or not.

Many experts would like to see the Russian Federation integrated in the international system at acceptable terms and thus avoid turning Moscow into an alienated pariah or a leader of those that coalesce against the international order where the West (even though with weakening unity) is still dominant. The question is whether internal developments in the Russian Federation can provide foundations for such developments. The main worries relate to economic matters that are fully subordinated to politics. With less integration in the world economy this tendency cannot be turned around as three-quarters of Russia's economic development is a result of implementation of western technology and methods of production. Russia exports nine times less than China, whereas its capital export is on the level of that of Denmark and equals approximately USD 150 billion.

Even in the post-Soviet space Russia does not realize its significant potential. It enjoys recognition for its symbolic leadership but is less successful in finding ways to turn leadership into economic opportunity. It suffices to mention that Chinese investments are 7-8 times larger than Russian investments in Kazakhstan. The effects of the sanction regime, often blamed for economic malaise by Russian leaders, are apparently more lasting than expected in Moscow. Furthermore, there is a consensus among macro-economists that the eventual lifting of sanctions would not result in increase of Russian export. Although Russia will continue to generate modest growth of about 1.5 to 2 per cent per year, this will not be sufficient to keep up the competition. In such a situation, if social dissatisfaction increases there is danger to "tighten the screws" and further rely on authoritarian means more than ever. It is also possible that the regime, noticing its declining popularity, steps back from adopting radical measures and continue to meddle. This might maintain social consensus in the foreseeable future but could contribute to decay in the long run. Furthermore, unlike the Soviet Union Russia invests in human potential, including education and healthcare, insufficiently and that further makes sustainability questionable.

The gap between performance and claimed status creates a situation where the broad array of communication is indispensable. While Russia has generally not been successful to diversify its strengths, it has increased the role of communication substantially. However, the problem of the world at large is not with Russia's strategic messaging. It is not necessarily with the so-called 'fake news' 
as it is possible to reveal such cases and embarrass Russia's leadership. The problem is with the broad array of measures, scattered from unfounded messages at one end to active measures and other ways of interfering in the domestic processes on the other. ${ }^{8}$ Further, Russian interference would spread from the disagreeable to the morally questionable, and further to the illegitimate and the outright illegal.

\section{Reaction to the Russian Strategic Communication Challenge}

When the West is facing the challenge to react to Russia's behavior it faces a number of sensitive asymmetries ranging from the unity of the Russian message to the consideration whether to react individually or collectively and thus the unity of the West's message. As the Russian Federation aims to mobilize (and demobilize) public opinion with its messages, western societies simply do not have the option to stand idle short of reaction. Furthermore, the dilemma is that the West is united by values, including the freedom of expression and the press, and thus it has to accept or at least tolerate various expressions of freedom of other countries, including ones that pursue malign intentions with their messages.

Modern societies are exposed to information more than ever before. We continuously receive news from various sources, and many of those news sources are not verified in regard to their content and intent. The print and mainstream electronic media is expected to be verified as far as the quality of its content. The social media from the onset has been regarded as uncontrolled and thus the 'most free.' However, as developments have illustrated, freedom must face limitations in order to safeguard the freedom of others and in order to protect the public interest also in this sphere. For states the problem stems from the fact that, short of lasting experience, it is difficult to agree on certain basic matters like the protection of the public without depriving it of access to information. For the societies, the problem is partly identical, and in part different. The similarity relates to the importance of protecting the people without unnecessarily depriving them from information, e.g. by some kind of censorship. The problem is different as far as societies do not have dedicated organizations and resources to react in a concentrated and time sensitive manner.

Clearly, the main challenge is due to the fact societies that are inadequately prepared to cope with the information their members receive. People are inad-

8 This may not be unprecedented as it happens between other actors and in other contexts as well. It was James Woolsey, former director of the CIA when asked on television whether the U.S. interferes in the domestic political processes of other countries, responded as follows: "Well... only for a very good cause. In the interests of democracy." Eric Boehm, "Former CIA Director and Fox News Host Share a Laugh Over American Interference in Foreign Elections: James Woolsey says America only interferes in other nations' elections "for a very good cause," but he can't keep a straight face while saying it," Reason, February 20, 2018. Accessed July 20, 2018, https://reason.com/blog/2018/02/20/former-cia-director-and-fox-news-host-sh. 
equately educated and face difficulties in selecting or deselecting the news and the interpretation that the media presents. Furthermore, genuine multilinguality is also an issue as most people tend to consume news in their first language (mother tongue). Hence, those providers that offer media content in the mother tongue of the audience enjoy comparative advantages. However, precisely in the post-Soviet context, it is necessary to qualify this. Namely, in several post-Soviet states the use of Russian language continues to be widespread, and in at least one, Belarus, it is actually used as first language. In several other countries Russian is widely used. This presents a challenge as Russia may have significant media influence in states ranging from Tajikistan to Ukraine.

It is open to question whether introducing some administrative measures, like taking channels out of the cable packages, is an adequate reaction. The democratically minded would possibly have the instinct not to advocate such radical steps. However, what if two countries are in high intensity conflict (war) and one intends to undermine the resolve of the other's society to fight. That is how Ukraine arrived at the decision to take Russian channels with significant news and propaganda content out of cable packages. Moldova followed Ukraine with a more limited effort of removing Russian news programs from the packages. In no way this should be interpreted as banning Russian television programs in those two countries. The programs remained accessible via internet and satellite. Nobody banned households from owning a satellite dish and in overwhelmingly Russian speaking habitations one could see a forest of such equipment. ${ }^{9}$ Although unwelcome, one may conclude that there are exceptional circumstances when it may be necessary to live with such temporary constraints introduced by Ukraine and Moldova. It may not be so well-known, but in some other former Soviet republics, e.g. Tajikistan, the number of accessible Russian channels has also been reduced. Again, in others, Georgia for example, the demand has dropped as particularly the younger generation lost Russian fluency and is interested in media in other languages, like in English, and their national programs.

Nevertheless, most states have no intention to ban Russian communication channels on their territory. Although in some cases, on the basis of reciprocity, administrative requirements of registration of Russian media outfits have been upgraded (e.g. in the U.S) as far as RT is concerned. It is open to question what would happen if some foreign media representations are obliged to wind up their activities in Russia (e.g. BBC). Will then states that are hosting Russian media feel compelled to reciprocate and, for instance, close RT in London.

The unity of the West faces delicate choices in responding to this challenge beyond eventual administrative measures. The West is a diverse entity and states may be exposed to different degrees and, hence, do not feel compelled to react in the same manner. There is also some division between the U.S. (and not

9 In the spring of 2018 , one could see a very dense forest of satellite dishes in the city of Odessa. 
because of the current leadership) and its European allies, most notably in regard to active counter-measures by using fabricated messages. Hence, this is one of the first issues in the search for an adequate framework, whether the reaction is national, international, or collective. There are some foundational points where consensus prevails: The credibility of the public electronic media and trust in the communication of the governmental forces are essential preconditions. In those countries where people generally trust their government and do not have reason to often doubt what the government says and does, it is more difficult for other countries to take advantage of discord between those who hold power and the population. There is illustration of this, including the failure of RT's attempt to gain influence in Sweden. In the Scandinavian country, efforts have been made to improve media literacy among schoolkids and youngsters, develop resilience and address fake news on time. ${ }^{10}$ There is also a complex link between a deeply split political class and the possibilities of gaining external political influence. When there is a broad political consensus on some foundations of the socio-political and socio-economic life and the international alignment of the country, ${ }^{11}$ external interference fostered by various media channels has less room.

Ant to the contrary - deep-seated internal divisions, cleavages in the society, unsettled international orientation help such external players that would like to use their influence. It suffices to mention some states of the western Balkans where building social cohesion has been unsuccessful. In some cases, the lack of success has ethnic grounds and also historic roots. It suffices to mention states like Bosnia and Herzegovina, where Russia is backing the Bosnian Serbs in order to maintain internal division and put pressure on the state of Bosnia and Herzegovina. In Serbia, Russia plays on orthodox Christianity like a civilizational foundation, in Croatia it speaks about the solidarity of Slavic nations, whereas in Northern Macedonia deeply divided internal politics and mutually exclusive agendas have provided the opportunity to interfere.

Communication appears on the most visible end that is backed by less visible forces ranging from diplomacy, and intelligence, to credits and investment. A corrupt establishment always appears helpful particularly in such small and poor countries where corrupting leaders does not incur unbearable costs. It is a further interesting feature of multi-layer Russian measures that when the leadership of a country is made dependent upon the Russian Federation, the latter usually pays less attention to achieving and maintaining decisive influence in the media space. It is sufficient to mention Hungary as an example, where the multichannel dependency of the government complemented by remarkable political stability make the focusing upon gaining bottom-up influence in the society redundant. And indeed, Russia is satisfied to benefit from using Hungarian proxy media channels to widen its influence in that country. Overall, it is fairly simple

10 For such efforts see https://www.stopfake.org/en/tag/sweden.

11 RT spread the fake news in its Spanish language program according to which Sweden would like to leave the EU. See "RT: Sweden wants out of the EU," July 14, 2016, https://www.stopfake.org/en/rt-sweden-wants-out-of-the-eu/. 
to summarize the factors of successful resilience of those states that do not intend to fall into dependency from Russia: good governance (its credibility, communication), national unity, and low level of corruption form part and parcel of it. Media literacy in the society, i.e. being able to make difference between truth and distorted messages, is an essential component of resilience. Hence, the level of political culture and efforts to develop it further matter a lot.

There are some highly successful examples, many of them in the Nordic and Baltic area, where attempts to increase the Russian influence had a rather limited effect. In those cases, there was a certain return to rely on traditional means. This is noticeable in the Nordic area, where Russia uses its public policy channels to reach out to both the Finnish and Swedish governments to warn them against approaching NATO. In the Baltic states the situation is understandably more complex due to the existence of large-though shrinking-Russian ethnic minorities. However, those states that have demonstrated more determination proactively, like Estonia, and where good governance has been unquestionable for a long time, Russian attempts, irrespective of media influence on e.g. the Russian speaking population of Estonia, have become more nuanced and reserved in order to avoid some further blunders. There can be hardly any doubt that the dedicated Russian institutions/personnel is waiting for the opportunity.

In recent years, the West had the opportunity to learn more about the ways and means by which Russian strategic messaging operates. There were some peaks in the series of events when Russian messaging contributed to concerns. If we take them in sequence.

The first event was the 2007 crisis with Estonia. The Estonian authorities removed a monument of the unknown soldier outside of the city center of Tallinn. Demonstrations followed by approximately one per cent of the city's population. That was skillfully presented by Russia as a much larger demonstration than it actually was and was used as a prelude to the first large scale but in no way decapitating cyber-attack that Russia aimed against Estonia. ${ }^{12}$

A few years later, the so-called Lisa case followed, when a 13-year-old Russian girl who lived in Germany disappeared from home. Allegedly, he was abducted and raped. In spite of Germany's denial, and sharing the available information with Russia through diplomatic channels, the Russian propaganda machinery continued its work. At the peak foreign minister Lavrov spoke about "Our Lisa." That was taken badly by Germany as the information indicating that Lisa had not been abducted and raped was available to the Russian MFA. ${ }^{13}$

12 Mark Landler and John Markoff, "In Estonia, What May be the First War in Cyberspace," The New York Times, May 28, 2007, accessed July 18, 2018, https://www.nytimes.com/2007/05/28/business/worldbusiness/28ihtcyberwar.4.5901141.html.

13 Stefan Meister, "The 'Lisa case': Germany as a Target of Russian Disinformation," NATO Review, www.nato.int/docu/review/2016/also-in-2016/lisa-case-germanytarget-russian-disinformation/EN/index.htm. 
Thirdly, when German forces were in charge of the temporary rotational deployment of a multinational unit of 800 strong multinational force in Lithuania, the news was spread that German soldiers raped a local woman. Again, it was apparently unfounded. However, it would have made possible to drive a wedge between the troops and the local population that must have been the intention. ${ }^{14}$

In the fourth case, in the spring of 2018, a former Russian - British double agent, Yuri Skripal and his daughter were poisoned in the town of Salisbury in the UK where they lived in exile. The West was of the view that the attempt was carried out by Russia. The Russian media raised doubts concerning the western version and presented a variety of facts that could weaken its persuasiveness, including the availability of the poison used in other states' arsenal, including the Czech Republic and Sweden. It was also argued, had it been the Russian state it would have done a perfect job, i.e. there would not have been any survivors. ${ }^{15}$ Overall 31 different versions appeared in rapid pace as far as the source of the chemical. This resulted in a smokescreen that in the end it was difficult to have an idea what really happened. Russia also fought in the Organization for the Prohibition of Chemical Weapons (OPCW), taking a proactive stance, putting forward initiatives to provide Russian experts with access to the crime scene and the British laboratory where Novichok could have also been developed. The UK attempted to put the burden back on Russia by providing as much transparency to the case as it was possible including naming the Russian perpetrators and those others involved and requesting their extradition from Russia. ${ }^{16}$ Even though a Russian security expert expressed the view that the Russian argument should not have changed so many times and should have rather stayed on message, it turned out that the Russian state did well for its own interest. In the end, except for the expert community, most people got tired with the case, lost track and interest in the matter - a success for Russian propaganda and public diplomacy.

What can we learn from the four cases presented briefly above? First, your own media space must be constantly monitored so that you could react in a timely manner if you are facing an attack. Secondly, various hostile activities are

14 Teri Schultz, "Why the 'Fake Rape' Story against German NATO Forces Fell Flat in Lithuania," Deutsche Welle, February 23, 2017, accessed July 18, 2018, https://www.dw.com/en/why-the-fake-rape-story-against-german-nato-forces-fellflat-in-lithuania/a-37694870.

15 "It's Quite Obvious That If It Were a Military-grade Nerve Agent, People Would Have Died on the Spot." - stated Vladimir Putin on 18 March 2018. See "Otvety na voprosy zhurnalistov posle zaversheniya vyborov Presidenta (Response to the questions of journalists following the closing of the Presidential elections)," http://kremlin.ru/ events/president/news/57085.

16 It is clear Russia in accordance with international law and its established practice will never extradite its own citizens for criminal procedure in another state. However, identifying suspects in person (names, photographs, etc.) makes the western message more credible and countering it more difficult, at least internationally. 
often linked. Consequently, when hostile activities begin in one area or with the use of one channel there is every reason to pay attention to a potential spillover not much later. Third, it is indispensable to present your version in a timely manner in order to counter the communication of the strategic opponent. Forth, it is essential that you stay on facts and do not reciprocate the lies of the other party by counter-factual reaction. Fifth, it has been a recurrent issue lately to decide in the beginning of the case how far the party attributing a communicationbacked attack to a state, e.g. to the Russian Federation, is ready to reveal its own sources. The opponent trying to raise doubts concerning your own version will act on the basis that you object to its version without providing adequate evidence. If you start an investigation to establish the facts, rest assured the other party will also start one and the conclusions that the latter investigation will draw will arrive at the opposite conclusion. Sixth, the entire exchange takes place in front of the public with the aim to convince it that you are acting in accordance with the truth, law, and you are representing high(er) morality. The public includes your national sphere of communication, that of your adversary and the so-called international community. Seventh, if communication is simplified to contrasting two rival versions of facts, the audience will remain divided and will remain with a fairly simple "either - or" question. That is why it is necessary to present your own version as part of a superior set of norms, principles and values in order to break out of the equation.

Bearing in mind the current divisions in the West, even though collective reaction to hostile strategic communication challenges is preferable to providing national responses in order to gain support of friends and allies. This has been applied in the so-called Skripal case where the British reaction was followed by massive demonstration of solidarity. The priority given to national reaction, with particular reference to its urgency, as the case in Lithuania mentioned above has demonstrated, shall not mean that international institutions cannot play a role. Their role may have to remain complementary and confined to those areas where they provide genuine comparative advantage. International organizations face a further problem - they often decide hesitantly in divisive matters and the Russian Federation often tries its best to prevent the establishment of unity in Western institutions.

Both NATO and the European Union have addressed the matter of strategic communication under the fast-changing conditions of the past few years. Their activity has reflected the potential of the institutions and the limits of the accord among the member states.

NATO first of all enhanced its capacity to collect and then analyze the information collected. On that basis, the Alliance has taken a proactive stance. It has established a Center of Excellence in Riga addressing the topic of strategic communication and, together with the EU, a similar center in Helsinki - the first such institution beyond NATO's territory. In Riga, the focus is on in-depth research of communication and also the development of methodology for the memberstates. It has to be considered that the Alliance cannot allocate large resources 
to this activity and hence member-states' commitment is essential to countering the Russian challenge. NATO has also become more active on the web. It has set the record straight by presenting Russia's views concerning the Alliance and its policies and contrasted them with facts and NATO's position. The fact that NATO's position has thus been presented in the form of rebuttal has attracted more attention of readers and the contrasted position makes it a better read. Its objective is partly to make Russian media understand that it cannot spread falsehoods as it is monitored by the "other side" and statements will not be left without reaction. NATO also asks such media to correct false stories. It is not the prime objective but also important to note that it has a "name and shame" element, i.e. a media that regularly presents counter-factual information and biased assessment can count with the attention of the Alliance's public diplomacy and can rest assured its activity is not left without reaction. In some cases, this requires coordinated action by NATO.

It was a memorable case when then Supreme Allied Commander in Europe, General Breedlove, achieved the declassification of satellite imaginary in order to have a solid foundation for making Russian military presence in Donbass clearly documented. NATO is guided in this activity by presenting its messages credibly and accurately, avoiding counter-propaganda and clearly contradicting Russia's communication.

The case of the EU is no less peculiar. First of all, the EU reacted belatedly to this emerging challenge, similarly to many other cases. This is due to the complex institutional framework and the massive need of excessive coordination among the member-states and the institutions. Stratcom East of the External Action Service has been established by "Conclusions of the Council." 17 Its three main objectives are:

1. communicating EU policy in the eastern partnership

2. strengthening the media environment, and

3. forecasting, addressing Russian "pro-Kremlin" disinformation with some emphasis on the crisis in and around Ukraine, as it is officially called.

Russian strategic communication presents a problem for the EU as it uses non-military means to achieve politico-military goals and is backed by massive resources. It suffices to mention that Russia invested 191 million Euro in Twitter, and is also active on Facebook. Russia also takes advantage of the more rapid dissemination of fake news - according to observations, fake news travels six times faster than truth on average. ${ }^{18}$ Its aim is to disorient and influence politi-

17 "European Council meeting (19 and 20 March 2015) - Conclusions," Brussels, March 20, 2015, EUCO 11/15, https://data.consilium.europa.eu/doc/document/ST-11-2015INIT/en/pdf.

18 See, for example, Robinson Meyer, "The Grim Conclusions of the Largest-Ever Study of Fake News: Falsehoods almost always beat out the truth on Twitter, penetrating further, faster, and deeper into the social network than accurate information," The 
cians and societies. It also tries to create confusion with the intention that people would lose orientation as far as facts. It uses stereotypes that are repeated frequently in order to be taken for granted by the addressees. Recently, these have entailed elements like "the EU is an U.S. vassal," "human rights defenders are targeted in the West," "the economic situation in the Baltic states is worse than in Soviet times," etc. It is essential that the stereotypes would address matters the overwhelming majority of the population is not aware of in detail. Although the activity of the EU in this area may be insufficiently visible, it has a website Eu vs Disinfo (https://euvsdisinfo.eu) that publishes not only analyses but also maintains a database of more than 3'800 disinformation cases since September 2015. Maybe the activity of the EU is less visible than it would be desirable, and yet it helps partly to provide access to sources for those that want to understand how the spreading of disinformation works and also sends a message to the originators of those messages that they cannot get away with their false messages for long.

The EU, once it started focusing on a matter, will not give up on addressing it quickly or easily. There are many examples illustrating this. In the area of tackling disinformation this has been demonstrated when the Commission passed a strategy paper on the topic following the European Council's conclusions three years earlier. ${ }^{19}$

\section{Conclusions}

The Russian Federation has not diversified its power base extensively. The only area where the broadening of the ways and means of power is essential has been strategic communication. Russia focused its efforts to reach out to the world at large with emphasis on areas closer to Moscow, and particularly to countries and societies which may be targeted by such communication. It has taken advantage of its ability to project a unified message, the West's commitment to freedom of speech and the media, and also benefited from the asymmetry due to the openness of the Western media market and the nearly fully controlled Russian one.

Russia's primary objective is to increase its weight in the international system and demonstrate its indispensable importance. As this can only partially be achieved by demonstrating some of Russia's undeniable strengths it has to simultaneously meet two requirements: reconfirm its power through communication and with this generate support and find followers, particularly in states and societies where Russia' influence is historically well-established or where it can be established with reference to some myths and, secondly, weaken the influ-

Atlantic, March 8, 2018, www.theatlantic.com/technology/archive/2018/03/largeststudy-ever-fake-news-mit-twitter/555104/.

19 "Tackling online disinformation: a European Approach," Communication from the Commission to the European Parliament, the Council, the European Economic and Social Committee and the Committee of the Regions, Brussels, April 26, 2018, http://ec.europa.eu/transparency/regdoc/rep/1/2018/EN/COM-2018-236-F1-ENMAIN-PART-1.PDF. 
ence of the West. The influence of the West is partly perceived to stem from its unity, including its institutions and those global ones where Western influence is regarded as too strong if not overwhelming by Russia, like the international financial institutions. Communication is part of the means put to use. However, this is by far not the full spectrum of Russian means of influence.

The media influence appears among the most visible new 'weapons' in the Russian arsenal. However, as most recent evidence shows, it is part of a spectrum where morally unacceptable, illicit and illegal means coexist. It suffices to mention the financing of certain political movements and parties (as the Soviet Union used to do with western Communist parties to no avail), interfering politically and technically into elections, providing patronage, entering into massively corrupt deals with foreign countries and their leaders, and thus contributing to regime stability of proxy regimes.

Russia's communication 'victory' is reflected in some weakening of Western unity and backtracking on values, including those foundational for democracy. Societies give priority to stability and strong leaders and take democracy for granted. However, no matter that Russia will do its best to portray these changes as its own achievements, this is only partially true. The faults of the West, its indecision, inadequate reaction to crises and bad leaders abusing power and placing priority on perpetuating themselves in office rather than addressing the most challenging matters are other contributing factors. As often is the case in international relations, the perception generated is essential. Demonstration of strength contributes to determine status and appears as self-fulfilling prophecy. A weak card played fairly well.

The West, similarly to many other situations, has remained hesitant, slow and divided in its reaction. Partly, as it faced a challenge where certain types of reaction would require reconsidering its foundational values, including an array of human rights, partly as appearing with a coordinated reaction, it is all the more difficult when the threat is not perceived as existential and hence the reaction could be delayed and indecisive. We could observe in the past years that the West has been gradually mounting its reaction in preservation of its superiority. It is still open to question whether the focus of the Western reaction will be on hostile strategic communication or other highly annoying activities, like influencing elections by political and technical means, and how the division of labor between national reaction and coordinated, international one will evolve. 


\section{About the Authors}

Prof. Dr. Ralf Roloff is Deputy Dean for Resident Programs at the Marshall Center since 2018 and Professor (apl), Universität der Bundeswehr München (since 2015). He was the Senior German Professor (2003-2018) at the College of International Security Studies at the Marshall Center. He is the Director of the Master in International Security Studies Program (since 2010). He was Director of the European Security Seminar (2015-2018).

E-mail: ralf.roloff@marshallcenter.org.

Dr. Pal Dunay is Professor of NATO and European Security Issues at the Marshall Center and Academic Advisor of its PASS, ESS-E, and SES courses. He was Director of the OSCE Academy between 2014 and 2016, Course Director of the International Training Course in Security Policy at the Geneva Centre for Security Policy (GCSP) between 1996 and 2004 and again between 2007 and 2014, Director of the Hungarian Institute of International Affairs in 2007 and senior researcher at the Stockholm International Peace Research Institute (SIPRI) between 2004 and 2007.E-mail: pal.dunay@marshallcenter.org. 


\section{Bibliography}

"European Council Meeting (19 and 20 March 2015) - Conclusions," Brussels, March 20, 2015, https://data.consilium.europa.eu/doc/document/ST-112015-INIT/en/pdf.

"Otvety na voprosy zhurnalistov posle zaversheniya vyborov Presidenta (Response to the questions of journalists following the closing of the Presidential elections)," March 2018, http://kremlin.ru/events/president/ news/57085.

"RT: Sweden wants out of the EU," Stopfake.org, July 14, 2016, https://www.stopfake.org/en/rt-sweden-wants-out-of-the-eu/.

"Tackling Online Disinformation: A European Approach," Commission to the European Parliament, the Council, the European Economic and Social Committee and the Committee of the Regions, April 26, 2018, http://ec.europa.eu/transparency/regdoc/rep/1/2018/EN/COM-2018-236F1-EN-MAIN-PART-1.PDF.

Baranets, Viktor, "V Pol'she zhdut yenki i gotovyat dlya nikh bordel (The Polish Are Waiting for the Yankees and Prepare Brothels for Them)," Komsomol'skaya pravda, May 31 - June 6, 2018, p. 4.

Boehm, Eric, "Former CIA Director and Fox News Host Share a Laugh Over American Interference in Foreign Elections," Reason, February 20, 2018, https://reason.com/2018/02/20/former-cia-director-and-fox-news-host-sh.

Dunay, Pàl, and Ralf Roloff, "Hybrid Threats and Strengthening Resilience on Europe's Eastern Flank," Security Insights 16 (March 2017), https://www.marshallcenter.org/MCPUBLICWEB/mcdocs/files/College/F_P ublications/seclnsights/security_insights_16.pdf.

Galeotti, Mark, "I'm Sorry for Creating the 'Gerasimov Doctrine'," Foreign Policy, March 5, 2018, https://foreignpolicy.com/2018/03/05/im-sorry-forcreating-the-gerasimov-doctrine.

Garamone, Jim, "NATO Commander Breedlove Discusses Implications of Hybrid War," U.S. Department of Defense, March 23, 2015, https://dod.defense.gov/News/Article/Article/604334/nato-commanderbreedlove-discusses-implications-of-hybrid-war.

Landler, Mark, and John Markoff, "In Estonia, What May be the First War in Cyberspace," The New York Times, May 28, 2007, www.nytimes.com/ 2007/05/28/business/worldbusiness/28iht-cyberwar.4.5901141.html.

Meister, Stefan, “The 'Lisa case': Germany as a Target of Russian Disinformation," NATO Review, 2016, www.nato.int/docu/review/2016/also-in2016/lisa-case-germany-target-russian-disinformation/EN/index.htm.

Menand, Louis, "Getting Real: George F. Kennan's Cold War," The New Yorker, November 6, 2011, https://www.newyorker.com/magazine/2011/11/14/ getting-real. 
Meyer, Robinson, "The Grim Conclusions of the Largest-Ever Study of Fake News: Falsehoods Almost Always Beat out the Truth on Twitter, Penetrating Further, Faster, and Deeper into the Social Network than Accurate Information," The Atlantic, March 8, 2018, www.theatlantic.com/technology/ archive/2018/03/largest-study-ever-fake-news-mit-twitter/555104/.

Schultz, Teri, "Why the 'Fake Rape' Story against German NATO Forces Fell Flat in Lithuania," Deutsche Welle, February 23, 2017, www.dw.com/en/whythe-fake-rape-story-against-german-nato-forces-fell-flat-in-lithuania/a37694870.

Vinocur, Nicholas, "Macron, Standing by Putin, Calls RT and Sputnik 'Agents of Influence'," Politico, May 29, 2017, https://www.politico.eu/article/macronand-putin-agree-on-restart-of-ukraine-talks. 